\title{
Disasters and Decentralisation
}

\section{Jason Scott Johnston}

Law and Regulation, University of Virginia School of Law, 580 Massie Road, Charlottesville, Virginia 22903-1738, U.S.A.

E-mail: jjohnston@virginia.edu

Climate change may potentially increase the magnitude of losses from natural hazards, but the United States experience shows that the primary reason for escalating losses is policy failure. It is well known that centralised, taxpayer-funded ex post disaster relief has actually encouraged development in risky jurisdictions and also weakened incentives for ex ante precautions in such jurisdictions (moral or "charity" hazard). Less well known and analysed is the role played by centralised ex ante development subsidies - often masquerading as protective investment -in distorting incentives. This paper develops a simple three jurisdiction model in which homogeneous jurisdictions decide by majority vote in a centralised legislature on the centralised (federal) share of ex post loss and centralised spending an ex ante development in a Beneficiary jurisdiction, taking into account how these decisions about centralised spending impact local Beneficiary jurisdiction incentives for precautions against ex post loss. The model shows that the marginal cost of ex ante federal development spending may be greater for a Beneficiary jurisdiction than for a Contractor jurisdiction. This somewhat technical result has an observable implication: evidence that a small fraction of ex post loss in a Beneficiary jurisdiction is centrally compensated (shared across jurisdictions) is evidence that ex ante development subsidies there may be truly precautionary on net; conversely, evidence that a Beneficiary jurisdiction has a large share of its ex post hazard loss compensated by centralised disaster relief suggests that the ex ante development subsidies received by that jurisdiction did more to encourage new development and increase the amount at risk than they did to protect existing development. The model is extended to consider how ex post loss sharing impacts the demand for federally subsidised disaster insurance and other related issues.

The Geneva Papers (2012) 37, 228-256. doi:10.1057/gpp.2012.13

Keywords: natural hazard; incentives; charity hazard; ex ante development subsidies; government disaster payments; majority approval

\section{Introduction}

The federalised natural disaster programme in the United States has four components that are crucial to incentives and therefore the size of overall losses from natural disasters. The first two aspects are well known. There is a relatively generous system of federal (that is, centralised) disaster relief under which taxpayers across the United States bear a share of the ex post loss realised in jurisdictions that have suffered a disaster such as a hurricane. Contrastingly, the precautions that may be taken to lower the amount at risk of loss in disaster-prone places remain primarily a responsibility of not the federal, but rather the local government. These two featurescentralised sharing of ex post losses together with local control over costly ex ante 
precautions - have generated a well-known moral hazard problem, whereby centralised sharing of ex post losses induces sub-optimal local incentives for ex ante precautions.

While well known, the local moral hazard problem continues. Solutions to this problem have been proposed, but cannot be successful unless account is also taken of two other features of the U.S. natural disaster programme. Both of these have to do with the system of centralised ex ante spending on what are typically called hazard protection projects, such as levees and seawalls designed to protect a coastal city from loss from hurricanes and other storms. These projects are rationalised as protecting existing development from loss due to natural hazards; in fact, they more often are both intended and have the effect of subsidising new development in lands that would otherwise be too risky or expensive to develop. Thus, centralised ex ante spending on projects that are supposed to lower the amount at risk from natural hazards may instead have the predominant effect of subsidising new development and actually increasing the amount at risk from natural hazards. Moreover, the final and politically crucial element of the natural disaster system lies in the fact that the benefits from centralised ex ante disaster protection projects typically do not fall entirely within the targeted Beneficiary jurisdiction, but are shared across jurisdictions. When levees are rebuilt in Louisiana, contractors from many states other than Louisiana get a share of the federal dollars being spent.

In order to evaluate potential solutions to the incentive problems arising from the U.S. natural disaster system, all four aspects of that system must be considered. In particular, what must be explained is continued majority legislative support for centralised ex post loss sharing. Such centralised loss sharing concentrates benefits in jurisdictions subject to natural hazards while spreading the costs across all jurisdictions in a federation. One mechanism by which such centralised ex post loss sharing might continue to be approved by a majority of the legislature is log-rolling: representatives whose constituents do not receive ex post loss sharing but bear the tax burden nonetheless support it because representatives of hazard-prone jurisdictions promise to support various projects that do benefit the constituents from representatives of taxed jurisdictions. In this article, I highlight and explain results from a simple but formal model in which majority support for ex post loss sharing emerges not as a consequence of log-rolling over time, but of the fact that ex ante development spending can be tied or linked to ex post loss sharing. The idea is that ex ante development subsidies benefit not only the hazard-prone jurisdictions where such development projects are located, but also contractors who are located in jurisdictions outside that which is exposed to the hazard. The externalisation of benefits from centralised ex ante development subsidies for hazard-prone jurisdictions provides a rationale for majority support of ex post loss sharing in those very same jurisdictions: ex post loss sharing does indeed distribute costs outside the hazard-prone jurisdiction, but ex ante development subsidies also distribute benefits to such jurisdictions.

As for ex ante local incentives for precaution, the model easily generates the typical (risk neutral) result that ex post loss sharing induces sub-optimal incentives for precautions. Less straightforwardly, the model shows that the benefits from centrally subsidised ex ante development projects may be smaller in jurisdictions where the projects are actually located than in jurisdictions where project contractors are located. This result has an observable implication: evidence that a small fraction of 
ex post loss in a jurisdiction is centrally compensated (shared across jurisdictions) is evidence that ex ante development subsidies there may be truly precautionary on net; conversely, evidence that a jurisdiction has a large share of its ex post hazard loss compensated by centralised disaster relief suggests that the ex ante development subsidies received by that jurisdiction did more to encourage new development and increase the amount at risk than they did to protect existing development.

The model is then extended to explain other widely observed and commented-upon facts about the U.S. disaster relief system, such as the impact of the federalised system of ex ante development subsidies and ex post loss sharing on the demand for insurance. It is shown that the demand for subsidised disaster insurance (as in the U.S. National Flood Insurance Program (NFIP)) varies inversely with the expected federal share of ex post losses but that the insurance subsidy may induce over-insurance with respect to the share of losses that are not compensated by federal taxpayers (even though the amount demanded may be less than total losses). The model is extended to examine one widely recommended policy for overcoming the moral (or charity) hazard problem induced by federal ex post loss sharing - making relief contingent on a hazard-prone jurisdiction's choice of optimal ex ante precautions. It is shown that if the federalised ex ante development project is not precautionary and instead simply increases the net amount at risk in the targeted jurisdiction, then such a jurisdiction will actually take optimal precautions only if it pays a very small part of the cost of the ex ante project and/or gets a large share of its ex post losses compensated, and also perceives a low probability of ex post loss.

Such analytical results are significant for several reasons. First, the incentives created by the U.S. disaster relief system will become more important if climate change - whatever its cause - increases the frequency or severity of coastal storms and hurricanes. For as Pielke Jr. et al. ${ }^{1}$ have shown, the long-term trend increase in losses from hurricanes that strike the coastal United States disappears when one controls for the rapid development of coastal areas. Without improved incentives for coastal development, losses will only get larger. Second and relatedly, if indeed the federally subsidised projects that the U.S. Congress authorises in the name of reducing the risk to existing development from natural hazards are actually development subsidies, doing more to increase potential loss from new development than they do to reduce the potential loss from existing development, then the problem of increasing coastal losses cannot be dealt with only by addressing the problem of inadequate local precautions. Instead, the system of ex ante federalised development subsidies itself must be curbed.

The existing economics literature has not formally analysed the role of such ex ante development subsidies in the U.S. natural disaster system. It has instead tended to focus instead on either explaining perceived failures of individuals and local governments to accurately estimate, insure and take precautions against natural hazard risk $^{2}$ or on alternative systems of financing ex post loss sharing. ${ }^{3}$ The relatively

\footnotetext{
${ }^{1}$ See Pielke and Landsea (1998) and Pielke et al. (2008).

${ }^{2}$ Kunreuther (1996).

${ }^{3}$ See, for example, Lewis and Murdock (1999).
} 
small economic literature on the political economy of the U.S. disaster system has focused as well on the system of ex post disaster relief. ${ }^{4}$

\section{Describing the pathology: the stylised facts of "natural" disasters and their regulation in the U.S.}

This part of the Article presents some of the crucial facts about the three central features of the U.S. natural disaster programme: generous federal (that is, centralised) sharing of ex post disaster losses; centrally funded ex ante development projects that may increase rather than reduce the amount at risk of loss in a natural disaster; and, finally, sharing of the benefits from ex ante project spending across a number of jurisdictions. The first of these, ex post loss sharing, has been written about extensively, while the second two are somewhat less discussed, but economically important aspects of the overall system.

\section{Ex post loss sharing}

The post World War II history of federal disaster relief in the United States presents a picture of increasingly generous federal sharing programmes with an increasingly severe problem of local moral hazard in the jurisdictions that benefit from such federal ex post loss sharing. Localities that get federal disaster relief have gotten more and more such relief, with a corresponding decrease in their incentives to spend money on ex ante precautions (or "mitigation" as it is known in the disaster literature). A variety of policy changes have been adopted with the goal of improving ex ante precautionary incentives - including shifting the cost of such precautions to the federal governmentbut none have been deemed to be a great success.

\section{Federal disaster relief}

The first "permanent and general" federal disaster relief law in the United States was the Disaster Relief Act of 1950, which initially covered only local public costs and was intended to help with the cost of repairing rural roads in recently flooded areas along the Red River in Minnesota and North Dakota. ${ }^{5}$ Congress originally intended the disaster relief programme to be limited in the amount of federal money provided, with federal relief contingent upon a presidential disaster declaration. ${ }^{6}$ In a series of laws passed between 1950 and 1980, however, Congress greatly expanded the scope of the federal disaster relief programme to include benefits to individuals, as well as public entities, and Congressional funding of disaster assistance has increasingly come from off-budget "supplementary appropriations" that are only sometimes offset with rescissions of prior disaster relief appropriations. ${ }^{7}$ While the amount of congressional

\footnotetext{
${ }^{4}$ See Kane (1996), Shugart (2006) and Congleton (2006).

${ }^{5}$ Platt (1999, p. 12).

${ }^{6}$ Platt, Disasters and Democracy at p. 15.

${ }^{7}$ Platt (1999, p. 24).
} 
disaster relief varies with the scope of the disasters funded, during the 1990s such relief averaged roughly $\$ 5$ billion per year (in constant 1993 dollars). ${ }^{8}$

Although Congress has not eliminated the Presidential disaster declaration requirement, it has passed laws that have both broadened the types of disasters to which the presidential declaration process applies, and added a new category of "emergencies" that are eligible for federal disaster relief. ${ }^{9}$ Between 1953 and 1994, there were 1,258 major disasters and 114 emergencies declared, with the fraction of disaster declaration requests granted rising from roughly two-thirds from the 1950 s to 1988 to 85 per cent in 1996, and direct federal assistance costs increasing from \$3.8 billion over the $1970-1981$ period to $\$ 34$ billion over the $1989-1994$ period. $^{10}$ After being administered by a variety of different federal agencies, in 1979 disaster relief became housed within the newly created Federal Emergency Management Agency (FEMA), where it resided until all of FEMA's responsibilities were transferred to the Department of Homeland Security by the 2002 Homeland Security Act. ${ }^{11}$

During the 1980s, both the Government Accountability Office (GAO) and a Senate Task Force called for more certain, objective criteria determining when disaster declarations should be issued, and for greater cost-sharing by states (increased state co-insurance, as it were). In response, Congress enacted the Robert T. Stafford Disaster Relief Act of 1988. ${ }^{12}$ That law increased the federal resources that states could receive and made state and local governments responsible for administering disaster relief. However, in language stating that "[i]n any major federal disaster, the president may direct any federal agency, with or without reimbursement, to utilise the resources granted to it under federal law ... in support of state and local assistance efforts", the Stafford Act gave the President virtually unlimited discretion in deciding whether to declare a disaster - a precondition for federal aid. That same law gave discretion to FEMA, an agency subject to Congressional oversight, in determining how to allocate federal disaster payments. The post-Katrina Emergency Management Reform Act of $2006^{13}$ expanded the range of types of financial assistance that can be provided by FEMA, but did not change presidential discretion in making the initial disaster declaration.

\footnotetext{
${ }^{8}$ Platt (1999, Tables $1-4$ at p. 25).

${ }^{9}$ Platt (1999, pp. 18-19). Disasters and Democracy at pp. 18-19. As amended, the relevant portion of the Disaster Relief Act, 42 U.S.C. $\$ 5122$ (2000) now reads: (1) Emergency- "Emergency" means any occasion or instance for which, in the determination of the President, Federal assistance is needed to supplement State and local efforts and capabilities to save lives and to protect property and public health and safety, or to lessen or avert the threat of a catastrophe in any part of the United States.

(2) Major Disaster- "Major disaster" means any natural catastrophe (including any hurricane, tornado, storm, high water, wind-driven water, tidal wave, tsunami, earthquake, volcanic eruption, landslide, mudslide, snowstorm or drought), or, regardless of cause, any fire, flood or explosion, in any part of the United States, which in the determination of the President causes damage of sufficient severity and magnitude to warrant major disaster assistance under this chapter to supplement the efforts and available resources of States, local governments and disaster relief organizations in alleviating the damage, loss, hardship or suffering caused thereby.

${ }^{10}$ Platt (1999, pp. 19-20, 22).

11 P.L. 107-296, November 25, 2002.

12 P.L. 100-707, 42 U.S.C. $\$ 5121$ et. eq.

13 Title VI, P.L. 109-295.
} 
There is now substantial empirical evidence that both Presidential disaster declarations and FEMA disaster expenditures are strongly influenced by political factors. Garrett and Sobel ${ }^{14}$ found that over the period 1991-1999, Presidents declared disasters at a significantly higher rate in states that were important in Presidential elections. They found, for example, that in 1996, a Presidential election year, there was a large increase in the number of Presidential disaster declarations, and that 90 per cent of the increase in disaster declarations occurred in the 12 so-called battleground states - states where the Presidential election was decided by 5 per cent or less. As for FEMA disaster expenditures, Sobel and Leeson found that states with representatives on the key Congressional committees that exercise oversight over FEMA got significantly more money from FEMA than states without such Congressional committee representation. Sobel and Leeson later summarised this as a finding that "nearly half of all disaster relief is motivated politically rather than by need". 15

Similar results were found by Downton and Pielke, who examined presidential disaster declarations that involved floods over the period 1965-1997. Controlling for total damage and precipitation, they found ${ }^{16}$ a 46 per cent increase in presidential disaster declarations during election years. The findings of Garrett and Sobel and Downton and Pielke have been confirmed and refined in subsequent work. Looking at a longer period of time, 1981-2004, Reeves found that the passage of the Stafford Act may well have politicised disaster declarations. He found that (controlling for all other potentially relevant factors) a state's electoral competitiveness had no impact on the rate of presidential disaster declarations over the period 1981-1989, but that over the period 1989-2004, an electorally competitive state could expect to get twice the number of disaster declarations as an electorally uncompetitive state. ${ }^{17}$ Thus, the evidence indicates that the U.S. federal disaster compensation system is one in which the share of local loss compensated federally may be quite high, or quite low, depending upon the political significance of the state in presidential elections and the representation of the state or district on key Congressional committees exercising oversight over FEMA.

\section{The NFIP and other forms of federal ex post relief}

The federal Disaster Relief fund is not the only source of federal disaster assistance. Indeed, there are about 30 federal programmes that offer some form of disaster service or compensation. ${ }^{18}$ Prominent among these are the NFIP, the Small Business Administration disaster loan programme for homes and businesses, the Farmers Home Administration disaster loan programme, the Federal Crop Insurance Program, and disaster-related Community Development Block Grants (CDBGs) issued by the department of Housing and Urban Development (HUD). ${ }^{19}$

\footnotetext{
${ }^{14}$ Garrett and Sobel (2003).

${ }^{15}$ Sobel and Leeson (2006, p. 61).

${ }^{16}$ Downton and Pielke (2001).

${ }^{17}$ Reeves (2011).

${ }^{18}$ Platt (1999, p. 26).

${ }^{19}$ Platt (1999, p. 28).
} 
Since 90 per cent of natural disasters in the U.S. are flood related, the most important of these is the NFIP. ${ }^{20}$ Under the NFIP, the federal government provides funding for flood insurance under policies that cover virtually all the contents and structure of a home against damage from flood. Private insurance companies sell the federal flood insurance policies under a programme known as Write Your Own and retain from premiums minor expense allowances and reimbursements. The federal government, however, assumes all the actual insurance risk. Since 1994, all properties within the 100-year floodplain and whose mortgages are written by federally insured lenders have been required to be covered by NFIP policies (and those policies max out at \$350,000 in coverage for single family homes and \$1 million for businesses). ${ }^{21}$ Since virtually all loans under $\$ 417,000$ are backed by either Fannie Mae or Freddie Mac, flood insurance is required of all mortgage loans in the 100-year floodplain up to that amount.

The NFIP was structured as a deal between the government as insurer and interest groups of the insured - homeowners, homebuilders and communities. ${ }^{22}$ Under the terms of this deal, the federal government would make available low-cost flood insurance but only to those property owners whose local communities enacted floodplain management regulations sufficient to meet minimum federal standards. ${ }^{23}$ Essentially every local community that could have opted into the NFIP has done so, with the number of participating communities holding roughly steady since $1999 .{ }^{24}$ A consistent pattern over the years is the concentration of NFIP coverage in coastal states: a 1997 study found that 58.7 per cent of NFIP policies and 62.8 per cent of insurance coverage in force were for coastal communities, ${ }^{25}$ a 2010 study $^{26}$ found that 40 per cent of NFIP policies were in Florida alone and almost 70 per cent of policies are held in the five coastal states of Florida, Texas, Louisiana, California and New Jersey.

Nevertheless, a long-standing perceived failure of the NFIP (at least 11 reports looked at the issue between 1973 and $2007^{27}$ ) is that it has never achieved anything close to universal participation by homeowners. In its first review of local enforcement of the NFIP insurance mandate, the Government Accounting Office found that while nearly everyone in Florida and Massachusetts bought flood insurance, nearly 80 per cent of homeowners in Texas and Maine did not. ${ }^{27}$ A more recent RAND Corporation study has found that regional variation in insurance take-up rates in 100-year floodplains continues to be high, with about 60 per cent participation in the south and west, but only around 20-30 per cent in the Midwest. ${ }^{28}$ Perhaps the most striking

${ }^{20}$ Platt (1999, p. 28) 28. The NFIP was established by the national Flood Insurance Act of 1968, 42 U.S.C. $\$ \$ 4001-4129$ (2000). Except where otherwise noted, the succeeding paragraph is based on Platt (1999, pp. 28-33).

21 Marron (2006, p. 2).

22 Platt (1999, p. 2) (citing May (1985, p. 19)).

23 Platt, Disasters and Democracy, at p. 28.

${ }^{24}$ See National Flood Insurance Program, Total Coverage by Calendar Year, available at http:// www.fema.gov/business/nfip/statistics/cy2006.cov.htm.

25 Platt, Disasters and Democracy, at p. 31.

${ }^{26}$ Michel-Kerjan and Kousky (2010).

${ }^{27}$ Lehrer (2008).

${ }^{28}$ Dixon et al. (2006). 
empirical phenomenon is the apparently low NFIP coverage rate in some of the riskiest coastal localities. In Orleans parish, which includes the city of New Orleans, the NFIP coverage rate was only 40 per cent when hurricane Katrina struck, and coverage in coastal Mississippi ${ }^{29}$ and some parishes in Louisiana was even lower. ${ }^{30}$

For properties constructed prior to the completion of local community's flood hazard map, insurance premiums under NFIP are subsidised, in the sense that they are not sufficient to provide a reserve for payouts in years with large, catastrophic losses. For such properties, FEMA estimates that the average NFIP premium is about 40 per cent of the actuarially fair rate (a subsidised rate of $\$ 710$ vs. an actuarially fair premium of \$1800). ${ }^{31}$ These are average premiums: for structures at the lowest elevation relative to the floodplain, actuarially fair, full-risk rates would be ten times higher than subsidised rates. ${ }^{32}$ Currently, about 22 per cent of NFIP policyholders - or around 1.2 million people-pay discounted premiums. ${ }^{33}$ This leaves only 78 per cent of NFIP policyholders who are paying premiums that theoretically allow the accumulation of sufficient capital reserves to pay large, catastrophic losses when they occur. However, importantly, the NFIP sets its premiums nationally, rather than on the basis of local history with natural hazards. ${ }^{34}$ With 22 per cent of premiums discounted and premiums based only on national averages, the programme is virtually certain to lack the reserves to deal with catastrophic losses. This is precisely what occurred after the severe Gulf Coast hurricanes of 2005. After Hurricane Katrina, the NFIP paid out more in claims than had been paid out over the entire life of the programme. About 122,000 of 200,000 damage claims reported by FEMA after Katrina (as of 30 November 2005), or 61 per cent were for subsidised properties. ${ }^{31}$ To cover the 2005 payouts, the NFIP borrowed from the Treasury, and remains in debt to the tune of approximately $\$ 19$ billion. ${ }^{33}$

The irony of the present insolvency of the NFIP is that the original justification for a programme of federally provided flood insurance was that private insurance companies would not cover flood damages because the catastrophic nature of floods causes flood damages to be lumpy and highly correlated across policyholders. ${ }^{35}$ However, the NFIP's premium structure ensures that it is no better able to accumulate adequate reserves against such catastrophic losses than is a private insurer. Current trends in NFIP coverage, moreover, suggest that the problem is only likely to get worse: from 1978 to 2007, four coastal southeastern states (Louisiana, Florida, Texas and Mississippi) received 75 per cent of the total amount paid under the programme, and by 2006 there were over 2.1 million NFIP policies (or 41 per cent of the total) in force in Florida, with almost $\$ 314$ billion in potential insured losses. ${ }^{36}$

\footnotetext{
29 Bayot (2005).

${ }^{30}$ See Michel-Kerjan (2010) and Kunreuther and Pauly (2006).

${ }^{31}$ Marron (2006, p. 5).

${ }^{32}$ Marron (2006, p. 6).

${ }^{33}$ Bin et al. (2011).

${ }^{34}$ Michel-Kerjan and Kousky (2010, p. 385).

${ }^{35}$ Young (2008).

${ }^{36}$ Pompe and Rinehart (2008).
} 


\section{Ex ante development}

\section{The NFIP and local incentives to control development}

There is a widespread perception that local communities have failed to keep up their end of the NFIP bargain by limiting floodplain development so as to reduce their vulnerability to loss from natural hazards. Even prior to passage of the NFIP, federal task forces were well aware that the cycle of "losses, protection and more losses" could only be dealt with if local communities took steps to "assure that their citizens would not unknowingly acquire and develop property where it is subject to known flood hazards". ${ }^{37}$ To encourage such sound local land use regulation, the NFIP from its inception incorporated four forms of mitigation: (1) identification and mapping of 100-year floodplains; (2) establishment of minimum federal standards for new construction in mapped floodplains; ${ }^{38}$ (3) charging actuarially fair rates for new construction; and, (4) authority for public purchase of flood-prone properties. ${ }^{39}$ The 1988 Stafford Act reiterated that state and local governments were only eligible for federal disaster monies if they took "appropriate action to mitigate ... hazards, including safe land use and construction practices". ${ }^{40}$ When Congress amended the NFIP in 1994, it acted to shift the cost of mitigation from states and localities to the federal level by providing NFIP coverage for the cost of bringing flood-prone structures up to federal standards, federal coverage of 75 per cent of the cost of state and local mitigation projects such as demolition and relocation of structures, acquisition of flood-prone properties, and beach nourishment, and discounted insurance rates for communities whose floodplain management regulations were tougher than federally required. ${ }^{41}$

The increased federal share under the NFIP was supposedly conditioned upon the adoption by states and localities of a new approach to disaster mitigation. Known as "sustainable hazards mitigation", this approach holds that "[h]azard mitigation activities should be linked to efforts to control and ultimately reverse environmental degradation by coupling hazard reduction efforts to natural resource management and environmental preservation". ${ }^{42}$ The new approach eschews structural fixes, such as levees and floodwalls in riverine environments and seawalls, revetments and groins in coastal environments. ${ }^{43}$ Instead, it prefers avoidance strategies such as floodplain buyouts in which people and property are removed from areas that are known to carry a

${ }^{37}$ Platt, Disasters and Democracy, at p. 77.

${ }^{38}$ The primary such standard is that the lowest floor of any structures built within the floodplain after the completion of the local flood insurance rate map must be elevated to or above the base flood level- the highest elevation at which there is a one per cent chance of flooding in any given year. U.S.G.A.O., Testimony before the Subcommittee on Housing and Community Opportunity, Committee on Financial Services, House of Representatives, Flood Insurance: Challenges Facing the National Flood Insurance Program (GAO-03-606T, 1 April 2003).

${ }^{39}$ Platt (1999, p. 77).

40 Platt (1999, p. 83).

${ }^{41}$ Platt (1999, p. 93).

${ }^{42}$ Mileti (2001, p. 31).

${ }^{43}$ Godschalk et al. (1999, p. 66). 
high risk. ${ }^{44}$ A primary example of the new approach to hazards mitigation is the Clinton Administration's response to the Midwest floods of 1993, which was to buyout and relocate people who were located in the riskiest floodplain locations. Using a combination of Section 404 Hazard Mitigation Grant Program (HMGP) ${ }^{45}$ (50 per cent) and HUD-administered CDBG (50 per cent) funds, "virtually all" mitigation in the state of Missouri after the 1993 floods consisted of floodplain buy-outs and relocations: for the summer, 1993 floods alone, some $\$ 60$ million was expended in buying approximately 2,400 primary residences, 1,100 mobile home pads, four apartment buildings and 38 vacant lots. ${ }^{46}$

Buy-out strategies have not, however, been uniformly successful. In Iowa, only 1,013 structures were purchased as mitigation after the 1993 flood, such a small number that instead of generating a continuous buffer of undeveloped floodplain, the buy-outs simply reduced the density of floodplain development, leaving unaffected the basic pattern of floodplain development. ${ }^{47}$ Over time, moreover, the clear trend in the NFIP has been a "decreasing emphasis on land-use planning and management in flood hazard areas". 48 The clear original objective of requiring "states and local governments to adopt and enforce meaningful restrictions over new construction and reconstruction in floodplains" was gradually but steadily softened; to the 1979 policy statement that although "avoidance of development in high hazard areas is the preferred approach", the "public interest" would be consistent with construction in high hazards areas given the lack of "suitable alternative"; to, finally, 1994's proposal to "develop and implement a process to encourage positive attitudes towards floodplain management". ${ }^{49}$ By 1995 , even state floodplain managers were complaining that:

Our flood policies have not embraced hazard mitigation and in part are to blame for escalating disaster damages. On an individual project basis, flood control projects have reduced flooding for design floods. But at the same time these policies have enticed additional development increasing the damage potential for severe floods, or have silently promoted the transfer of flood damage from one property to another. Likewise, with a benevolent federal government, there has

\footnotetext{
${ }^{44}$ Godschalk et al. (1999, p. 67).

${ }^{45}$ Administered by FEMA, the HMGP was created in 1988 by Section 404 of the Stafford Disaster Relief and Emergency Assistance Act. According to Godschalk et al., Natural Hazard Mitigation, p. 393, "[t]he purpose of the Section 404 program is to assist states and local communities in implementing long-term hazard mitigation measures following a presidential disaster declaration". Originally limited to 10 per cent of the federal assistance provided under the Public Assistance Program under Section 406 of the Stafford Act and as much as 50 per cent of a project's total cost, the Volkmer Act of 1993 increased the cap on HMGP funding to 15 per cent of the estimated federal assistance under both the Public Assistance and Individual Assistance programmes. Godschalk et al. (1999, p. 394).

${ }^{46}$ Godschalk et al. (1999, p. 169).

${ }^{47}$ Godschalk et al. (1999, p. 205). Over the entire period 1988-1995, 58 per cent of HMGP funds obligated were for acquisition and relocation projects, but more than 81 per cent of these were obligated in 1994 as a result of the 1993 midwest floods. Godschalk et al. (1999, p. 413).

48 Platt (1999, p. 94).

${ }^{49}$ Platt (1999, pp. 95-96).
} 
been little incentive at the local and state levels of government to minimize the creation of new hazards. ${ }^{50}$

As Platt aptly summarises its evolution, the National Policy on the role of local land use regulation in floodplain loss mitigation had "shifted from mandatory local regulation pursuant to minimum federal standards to cultivation of 'positive attitudes' and 'public understanding'". ${ }^{51}$ Given this progressive and steady weakening of controls over local development, it is perhaps unsurprising that more than one-third of the 6.6 million buildings in the 100-year floodplain of NFIP communities were built after the start of the NFIP. ${ }^{52}$ As Pompe and Rinehart ${ }^{53}$ conclude, the net effect of the NFIP has not been to move development away from hazardous areas, as it was originally intended to do, but rather to encourage more development in high risk areas.

Federal ex ante hazard reduction as a disguised development subsidy

An additional weakness in all recent schemes to improve local incentives in natural hazard regulation is that they fail to really analyse the interaction between federal development subsidies - implemented by project agencies such as the Army Corps of Engineers - and the federal disaster relief programme. It is not that people do not recognise the problem. One commentator has recently complained that federal insurance and relief programmes have subsidised development in hazard-prone areas, and the expectation of federal assistance even after repeat losses has created a severe moral hazard problem, ${ }^{54}$ while risk reduction and risk transfer policies have:

effectively shifted liability for the occupation of hazardous areas to Washington and to a lesser degree state capitols, thus relieving local governments of their traditional responsibility for managing these areas. The federal and state government top-down approach to dealing with local stakeholders has done little to foster the "local involvement, responsibility and accountability" called for in the most recent comprehensive review of federal policy. ${ }^{55}$

Yet the very same commentator admits that local governments have a limited ability to use land-use management for natural hazard mitigation, because "increased exposure of people and property to flooding has been abetted by federal financing of highway construction, sewers, and other infrastructure that increase development potential in flood-prone areas while also reducing development costs". 56

\footnotetext{
${ }^{50}$ Platt (1999, p. 40), quoting Doug Plasencia, Testimony of the Association of State Floodplain Managers before the Senate Subcommittee on Transportation and Infrastructure, 14 February 1995.

${ }^{51}$ Platt (1999, p. 96).

52 Burby (2001).

${ }^{53}$ Pompe and Rinehart (2008, p. 197).

${ }^{54}$ Mileti (2001, p. 158).

55 Mileti (2001, pp. 158-159).

${ }^{56}$ Mileti (2001, p. 159).
} 
Indeed, the traditional approach to federal natural hazard management in fact construes development projects as natural hazard control projects. A prime example of this is the lower Mississippi. Before the Corps of Engineers' Mississippi flood control projects, silt from the great river constantly replenished marshes and coastal barrier islands that provided natural protection for New Orleans against coastal storms. ${ }^{57}$ Without the silt, the coastline has eroded, leaving New Orleans without natural defences to storms such as Katrina. Similar examples abound: "[i]n the United States the settlement of hazardous areas has destroyed local ecosystems that could mitigate those hazards. Draining swamps in Florida or bulldozing steep hillsides in California for homesites are examples of human actions that expose more people to natural hazards while destroying natural systems that would have helped minimize flooding". 58

Similarly, for all the talk about "sustainable mitigation", the first response to Katrina has been to question the soundness of the levees and to begin spending billions of dollars on a new, stronger levee system. While widespread, such reaction misses a central lesson about the Army Corps of Engineers hurricane protection projects: historically, those projects have been intended more to "reclaim" marshlands for development than to protect natural drylands from hurricanes. Such projects have implemented what Burby calls the federal policy of "safe development": making land exposed to natural hazards profitable for development. ${ }^{58}$

This is dramatically illustrated by the history of Hurricane Betsy, which breached the levees of Lake Pontchatrain in September 1965, causing massive damage to New Orleans and vicinity. Although it was once disputed, it is now generally agreed that the Mississippi River Gulf Outlet (abbreviated as MRGO), which sliced a 500-foot wide channel through the otherwise meandering and ever-shifting Mississippi River Delta, had acted to funnel and therefore exacerbate damage from hurricane storm surge hitting New Orleans. ${ }^{59}$ MRGO was built as a development project: to improve the Port of New Orleans and allow it to compete for the international grain trade against the St. Lawrence Seaway. Even as it brought development benefits, however, MRGO increased the expected harm from hurricanes.

The response to Betsy over the period 1965-2005 illustrates just as dramatically how centralised projects that are ostensibly about natural hazard protection actually have their most direct impact in generating new development and thus increasing the potential loss from natural hazards. According to Colten and Sumpter ${ }^{60}$ a clear lesson from Betsy was that eastern New Orleans, the lakefront of Lake Pontchartrain and the downstream parishes of Plaquemines and St. Bernard were most vulnerable to floods. Rather than reducing development in these areas, the Corps of Engineers built new hurricane protection levees around these areas, and local government made no effort to shift development away from these areas but instead actually encouraged it. Indeed, the Orleans Levee District Board - supposedly responsible for maintaining its existing levees - used its eminent domain powers for "flood-control" projects to build behind

\footnotetext{
${ }^{57}$ See Wisner et al. (2004, p. 204).

${ }^{58}$ Burby (2006, pp. 174-175).

${ }^{59}$ See Shallat (2000, p. 133) who notes that by the mid-1970s it was clear that MRGO had destroyed some 3,000 acres of marsh in the Delta that had provided natural protection against hurricane storm surge.

${ }^{60}$ Colten and Sumpter (2009, p. 360).
} 
the Lake Pontchartrain levees two marinas, a casino and roads, a dock and a commuter airport to bring people to them. ${ }^{61}$

The post-Betsy development of New Orleans East depicts not only how federal projects encouraged new development in the most vulnerable areas, but also how many of the benefits of such new development went to out-of-state developers who would bear none of the cost of a future natural hazard. A group of investors from Texas including Lady Bird Johnson, the wife of the then President of the United States Lyndon Johnson, wanted to build a levee so as to drain 32,000 acres of marshland in eastern New Orleans through which an interstate highway extension was planned for a new development to be called New Orleans East. Their development would be feasible only with the extension of the New Orleans area levee system to the area east of the Industrial Canal. Happily enough for those investors, they were able to get their levees paid for by the federal government as part of the Army Corps of Engineers flood control projects undertaken as a response to Betsy. And they were not alone, for in the aftermath of hurricane Betsy, over $\$ 250$ million of centralised (that is, federal) money was spent by the Army Corps of Engineers on the "Lake Pontchatrain and Vicinity, Louisiana, Hurricane Protection Project". This project raised existing levees and constructed new levees along much of the southern shore of Lake Pontchatrain. ${ }^{62}$ In the cost-benefit analysis statutorily required for this Project to gain approval, only 21 per cent of the benefits from the project were from protection of existing development; a somewhat astounding 79 per cent of the project benefits were to come from new development that would be made economically feasible by the new levee system. ${ }^{63}$ And the Lake Pontchatrain project did indeed spur new development: in a process that one commentator called an "explosion" of metropolitan New Orleans "into the swamps", during the decade after the Project was authorised by Congress, Jefferson Parish added 47,000 housing units and Orleans Parish added 29,000 units. As for New Orleans East, the area developed by Texas investors including the President of the United States, between 1970 and 2000, that area of former undeveloped swampland (plus another eastern development called Orlandia) added 22,000 new housing units. ${ }^{64}$

These projects thus clearly had their intended effect of subsidising and hence stimulating development in hazardous areas. ${ }^{65}$ As for whether the post-Betsy projects had any actual net precautionary, or hurricane-protective value, the evidence suggests precisely the opposite - that these ex ante development subsidies actually reduced the marginal productivity of local precautions. ${ }^{66}$ After Betsy, it was clear that when levees are built and the wetlands behind them drained for new development, the reclaimed land begins to subside, eventually sinking well below sea level and forming a bowl behind the levees. It was also clear, after Betsy, that when a hurricane strikes, these levee-created bowls of subsiding land fill with water. With a vastly expanded ring of levees after Betsy, there was a vastly larger area that would need to be evacuated in the

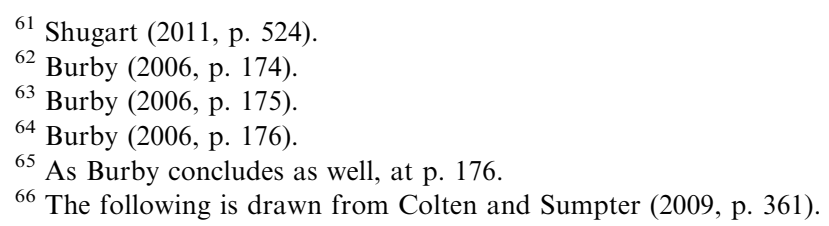


event of hurricane. Hence, relatively low cost and widely accessible local evacuation would no longer be an effective response to a hurricane; rather, large numbers of people would have to evacuate by automobile, using the interstate highways to get well outside the leveed urban area. Thus, the federally funded expansion in the levee system eliminated entirely the old relatively cheap option of local evacuation, and forced reliance upon a much more expensive system of interstate evacuation by car. And for the 27 per cent of New Orleans residents who did not own a car, the expanded levee system forced reliance on a system of bus transportation to localised shelters that proved to be a catastrophic and tragic failure. ${ }^{67}$

Investigations into the cause of the catastrophic harm suffered as a consequence of hurricane Katrina add further support to the notion that the post-Betsy levee system was more about promoting new development than about protecting existing areas from harm. For one thing, the post-Betsy projects were done on a project-by-project basis over a number of years, a pattern that clearly generated benefits for project contractors and local land developers but - as shown by hurricane Katrina - did not produce an effective hurricane protection system. ${ }^{68}$ Moreover, what engineers identified as the unique and paradoxical feature of the Katrina disaster - that the devastating harm was the result of obvious failures to follow basic engineering guidelines in designing and maintaining levees that failed to prevent the very disaster they were supposedly intended to protect against ${ }^{69}$ - is neither surprising nor paradoxical if one views the levees as subsidised ex ante land development projects, rather than protection against ex post risk.

\section{Shared benefits from ex ante development projects}

Studies of pork-barrel spending often suppose that the benefits from federally subsidised projects fall entirely within the jurisdiction where the project is undertaken. ${ }^{70}$ This is not generally true. As indicated by the example of the Texas investors who directly benefited from the development of New Orleans East made possible by the federally subsidised levee system built by the Army Corps of Engineers, substantial benefits from centralised projects often go to people who reside outside the jurisdiction where the project is located. Moreover, whatever the federally subsidised project-be it construction of a dam, cleanup of a hazardous waste site, or dam or leveecontractors are often based outside the jurisdiction where the project is located. Hence, much spending on federally subsidised projects goes to people located in jurisdictions that are not direct beneficiaries. Army Corps of Engineers project spending clearly illustrates this. Consider the example of Army Corps of Engineers project spending in the New Orleans area in the aftermath of hurricane Katrina. As of January 2011, the Corps had spent over $\$ 7$ billion on such projects and awarded contracts to 65 firms. ${ }^{71}$

${ }^{67}$ Cutter and Gall (2007).

${ }^{68}$ See American Society of Civil Engineers (ASCE 2007, p. 22).

${ }^{69}$ ASCE (2007, p. 47).

${ }^{70}$ See, for example, Hird (1994).

${ }^{71}$ See U.S. Army Corps of Engineers New Orleans District, HSDRRS Construction Contractors Contract Awards, available at (finish). 
Of these 65 firms, only 40 were local, meaning from Louisiana, while such local contractors got a little over $\$ 4$ billion of the roughly $\$ 7$ billion spent, or 58 per cent. This is an important but often overlooked stylised fact of centralised spending on projects related to natural hazard losses.

\section{A simple model of the disaster paradox: centralised development subsidies and $e x$ post disaster relief, decentralised control of precautions}

The natural hazards literature depicts a paradox of sorts: a system in which large ex ante centralised development subsidies (in the form, most dramatically of Army Corps of Engineers project spending) has massively increased the scope of potential ex post loss from natural hazards, and yet the federal share of such ex post loss has remained high, especially in places where it has already been high. At the same time, although there is a widespread perception that ex post disaster relief has weakened incentives for local ex ante precautions to lower the amount at risk of ex post loss, such precautions remain weak and the share of ex post loss compensated by the federal government has, if anything, increased. Together, the combination of federal ex ante development subsidies and federal ex post disaster insurance and relief schemes have not only increased the scale of private development, massively increasing the size of natural hazard losses, but also literally created natural hazards by making millions of acres of land economic to develop that would never have been developed otherwise. In order to properly analyse alternative policy fixes for this paradoxical pattern of centralised subsidisation, we must first have a model that would explain, as a purely positive matter, this pattern.

There are a variety of candidates for such a model, but here I describe and explain results from a model that focuses on the potential linkage in a federal legislature of ex ante development subsidies and ex post loss sharing. To construct such a model, I first consider a simple federation consisting of three jurisdictions, each of which consists of homogeneous resident-voters and thus may be thought of as a single actor. The three jurisdictions are: (1) a beneficiary jurisdiction, where the project is located and where the natural hazard may strike; (2) a contractor jurisdiction, whose firms perhaps help with the project construction in the beneficiary jurisdiction, thereby gaining not only profits but also experience and human capital formation benefits; and, (3) the loser jurisdiction, which gains no benefits from the project at all. I assume that jurisdictions have fixed types (Beneficiary, Contractor or Loser). This assumption generally matches the stylised facts, given that some jurisdictions (e.g. the state of Louisiana) are disaster-prone and tend to be Beneficiaries, while others (e.g. the state of Virginia) are home to large contracting firms. ${ }^{72}$

The question before the central, three-jurisdiction legislature is whether to approve and fund a development project for the Target jurisdiction of size $g$, and to determine

\footnotetext{
${ }^{72}$ In an alternative world, where each jurisdiction has some chance of being any given type in the gameBeneficiary, Contractor or Loser - there would be quite different conditions for majority support for both ex ante development subsidies and ex post disaster compensation. While interesting, analysis of such a world is beyond the scope of the present paper.
} 
the share, $s$, of natural hazard losses that will be compensated out of a central fund. Centralised legislature decisions are taken by a single issue up-or-down majority vote.

That vote is taken subject to complete information regarding the following. First, I assume that both the cost of any ex ante development project, $g$, and the cost of compensating ex post a share $s$ of ex post loss is divided among the beneficiary, contractor and loser jurisdictions according to the respective shares $t_{b}, t_{c}$ and $t_{1}$. Initially, I will assume that the shares $t_{i}$ are determined outside the model, as would be the case if both the ex ante development project and ex post disaster relief were paid for by income tax revenues. This assumption will be relaxed later to consider the case where shares are determined as part of the project funding and disaster relief game. Continuing with notation, let the value to the Beneficiary and Contractor jurisdictions from a project of amount $g$ be given, respectively, by continuous functions $V(g)$ and $v(g)$, with $V^{\prime}(g)>0, v^{\prime}(g)>0$ and $V^{\prime \prime}(g)<0, v^{\prime \prime}(g)<0$. The natural hazard-for example a hurricane or flood - occurs with a probability $p$ that is exogenously determined (e.g. by weather, climate and the location of the beneficiary jurisdiction). The amount of harm suffered by the beneficiary in the event that the natural hazard is realised, denoted by $H$, is determined by the size of the development project, $g$ (which indirectly determines the level of overall development and hence the loss from the hazard), and also by the level of precautions, $x$, taken the beneficiary to lower its natural hazard loss. Hence, we have that $H=H(g, x)$, with $\partial \mathrm{H} / \partial \mathrm{g}>0, \partial \mathrm{H} / \partial \mathrm{x}<0, \partial^{2} \mathrm{H} / \partial \mathrm{g}^{2}<0$ and $\partial^{2} \mathrm{H} /$ $\partial \mathrm{x}^{2}>0$. The cost of precaution, borne entirely by the Beneficiary jurisdiction, is given by $c(x)$, with $c^{\prime}(x)>0$ and $c^{\prime \prime}(x)>0$. To use the now standard terms in the literature, ${ }^{73}$ I am thus assuming that with natural hazards, there is no opportunity for selfprotection, but only self-insurance, in that precautions $x$ effect only the size of the ex post loss, with no impact on the probability of its occurrence.

Note that by assuming $\partial \mathrm{H} / \partial \mathrm{g}>0$, I have assumed that the centralised investment is indeed in infrastructure that on balance increases the expected loss from the natural event (hurricane, for example). This assumes that even if the centralised investment is in a levee that reduces the amount at risk in some locations within the Beneficiary jurisdiction, it increases the amount at risk by more elsewhere. Later I shall explore the consequences of altering this assumption by assuming instead that the centralised investment really is precautionary, in that it reduces the potential loss from the hazard (viz. that $\partial \mathrm{H} / \partial \mathrm{g}<0$ ).

The centralised legislature, the Beneficiary and nature play a three-stage game:

In the first stage, the centralised legislature determines the development project level $g$ and the natural hazard relief share $s$.

In the second stage, the Beneficiary determines the level of precautions, $x$, against natural hazard loss.

In the final stage, the natural hazard does or does not occur and the benefits $V()$ and $v()$ are realised.

${ }^{73}$ As in, for example, Ehrlich and Becker (1972), Dionne and Eeckhoudt (1985) and Jullien et al. (1999). 


\section{The final stage solution: Locally optimal precautions}

Because the three member legislature has complete information, its members all take account of how their majoritarian decision regarding $g$ and $s$ affect the final stage decision of the Beneficiary regarding the level of precautions to lower natural hazard loss. Hence, the game must be solved by first identifying the level of precautions chosen by the Target. I begin by assuming that the Beneficiary is risk neutral, and thus chooses its level of precautions so as to minimise the sum of the cost of precautions and the expected loss from the hazard. The problem facing such a Beneficiary is given by:

$$
\left.\min _{x} p\left(1-s\left(1-t_{b}\right)\right) H(g, x)\right)+c(x) .
$$

The solution to this problem will be denoted by $x_{b}(g, s)$ or when there is no risk of confusion simply by $x_{b}$. Observe that the Beneficiary considers only the share $\left(1-s\left(1-t_{b}\right)\right) H$ of harm that goes uncompensated, after taxes, by the other jurisdictions. The first order condition defining an interior solution $x_{b}$ to (1) is:

$$
\partial H / \partial x p\left(1-s\left(1-t_{b}\right)\right)+c^{\prime}(x)=0 .
$$

Using the earlier assumption that $\partial^{2} H / \partial x^{2}>0$ and the implicit function theorem, we also have that:

$$
\begin{gathered}
\frac{\partial x_{b}}{\partial p}=\frac{-\partial H / \partial x\left(1-s\left(1-t_{b}\right)\right)}{\partial^{2} H / \partial x^{2} p\left(1-s\left(1-t_{b}\right)\right)+c^{\prime \prime}(x)}>0, \\
\frac{\partial x_{b}}{\partial s}=-\frac{p\left(1-t_{b}\right) \partial^{2} H / \partial x^{2}}{\partial^{2} H / \partial x^{2} p\left(1-s\left(1-t_{b}\right)\right)+c^{\prime \prime}(x)}<0,
\end{gathered}
$$

and,

$$
\frac{\partial x_{b}}{\partial g}=-\frac{p\left(1-s\left(1-t_{b}\right)\right) \partial^{2} H / \partial x \partial g}{\partial^{2} H / \partial x^{2} p\left(1-s\left(1-t_{b}\right)\right)+c^{\prime \prime}(x)} .
$$

Eqs (3)(a) and (b) are intuitive: the Beneficiary's optimal level of precautions increases, the higher the probability of loss, and decreases, the higher is the share of the loss borne by other jurisdictions. The sign of Eq. (3c) is of ambiguous. Given the assumption that $\partial^{2} H / \partial x^{2}>0$ and $c^{\prime \prime}(x)>0$, Eq. (3c) says that the effect of increases in the size of the centralised development project on local incentives for natural hazard precautions depends upon how increases in centralised ex ante project spending impact the marginal productivity of ex post local precautions. If increasing project size increases the marginal productivity of local precautions $-\partial^{2} \mathrm{H} / \partial \mathrm{x} \partial \mathrm{g}<0$ - then locally 
chosen precautions increase with project size; if, conversely, increasing project size diminishes the marginal productivity of local natural hazard precautions $-\partial^{2} \mathrm{H} /$ $\partial x \partial g>0$ - then the locally optimal level of precautions falls as the centralised project gets larger.

The first stage solution: bargaining over federal ex ante development spending and ex post loss compensation

To solve for equilibrium behaviour at the first stage, observe that Loser jurisdiction gain nothing from either a centralised development project or a centralised disaster loss sharing, and thus the Loser will vote against any $g>0$ and $\mathrm{s}>0$. Any levels of $g>0$ and $s>0$ chosen by centralised majority rule are therefore solely a function of the payoffs to the Beneficiary and Contractor jurisdictions.

To formally identify potential combinations of $g$ and $s$ that will make both the Beneficiary and Contractor better off relative to a status quo payoff of 0 , we need to formally specify their payoff functions. Given an anticipated locally optimal choice of precautions $x_{b}$. The expected benefit to a given Beneficiary from federal development spending in the amount $g$ and federal compensation for a share $s$ of disaster loss is now given by:

$$
\begin{aligned}
& (1-p)\left[V(g)-t_{b} g\right]+p\left[V(g)-t_{b} g-(1-s)\right. \\
& \left.\quad \times H\left(g, x_{b}\right)-t_{b} s H\left(g, x_{b}\right)\right]-c\left(x_{b}(g, s)\right)
\end{aligned}
$$

or simplifying:

$$
V(g)-t_{b} g-p H\left(g, x_{b}\right)\left(1-s\left(1-t_{b}\right)\right)-c\left(x_{b}(g, s)\right) .
$$

Similarly, the expected benefit to the Contractor jurisdiction from the package $(g, s)$ is given by:

$$
(1-p)\left[v(g)-t_{c} g\right]+p\left[v(g)-t_{c} g-t_{c} s H(g, x)\right] .
$$

or, simplifying:

$$
v(g)-t_{c}(g+s p H(g, x)) .
$$

Expression (4) reveals a complimentarity between ex ante development subsides and ex post loss sharing. When the Beneficiary jurisdiction pays a small fraction of the ex ante cost - meaning $t_{b}$ is small - then it can get a positive expected payout even when the centralised share of the ex post loss, $s$, is small. This suggests that we should observe poor jurisdictions accepting centralised development grants even when they must bear a relatively large share of any ex post hazard loss, while richer jurisdictions, paying a higher fraction of costs both ex ante and ex post, will accept the project only if the ex post losses are shared more fully by the other jurisdictions. 
More detailed inquiry into the model's implications for the relationship between ex ante development subsidies and ex post disaster relief require a consideration of optimising behaviour, and it is to that I now turn.

\section{Contractor and beneficiary optimal levels of federal ex ante development spending}

From (4) and (5), we can solve for the optimal levels of ex ante centralised development spending from the point of view of both the Beneficiary and the Contracting jurisdiction. From (4), we have that at an interior optimum, the Beneficiary's optimal level of ex ante development subsidy, $g_{b}$ is defined by the first order condition:

$$
\begin{aligned}
V^{\prime}\left(g_{b}\right)-t_{b}-p & {\left[\frac{\partial H}{\partial g}\left(g, x_{b}\right)+\frac{\partial H}{\partial x}\left(g, x_{b}\right) \frac{\partial x_{b}}{\partial g}\left(1-s\left(1-t_{b}\right)\right)\right] } \\
& +\frac{\partial x_{b}}{\partial g} c^{\prime}\left(x_{b}\right)
\end{aligned}
$$

The envelope theorem simplifies this to:

$$
V^{\prime}\left(g_{b}\right)=t_{b}+p\left(1-s\left(1-t_{b}\right)\right) \frac{\partial H}{\partial g\left(g, x_{b}\right)} .
$$

Eq. (6) shows the two components of the Beneficiary's marginal cost of increasing the development subsidy $g$ : (i) the direct tax cost $t_{b}$, and (ii) its share of the increased expected harm from a higher level of development, given that it chooses its precautions optimally.

Consider next the Contractor's optimal level of ex ante subsidy, $g_{c}^{*}$. This is defined by the first order condition:

$$
v^{\prime}\left(g_{c}\right)=t_{c}\left[1+s p\left(\frac{\partial H}{\partial g}+\frac{\partial H}{\partial x} \frac{\partial x_{b}}{\partial g}\right)\right] .
$$

When we compare (7) with (6), we see immediately that there may be an additional ambiguity in the Contractor's optimisation problem caused by the fact that the Contractor does not internalise the cost of precautions taken by the Beneficiary. The ambiguity lies in the term $\partial x_{b} / \partial g$, which could, as explained earlier, be either negative, positive or zero. By the earlier assumptions, we have that $\partial H / \partial g>0$ and also $\partial H / \partial x<0$, we could only have $d H / d g=(\partial H / \partial g)+(\partial H / \partial x)\left(\partial x_{b} / \partial g\right)<0$ if increasing the level of federal development spending had such a large effect in increasing the productivity of local precautions - so that $\partial x_{b} / \partial g>0$ - that the effect of increased precautions outweighed the direct effect of increased project size (that is, if $|\partial H / \partial g|<$ $\left.|\partial H / \partial x|\left|\partial x_{b} / \partial g\right|\right)$. This seems highly unlikely; indeed, were it the case, then the logical question would be why such an increase in productivity could not be stimulated with an even lower level of centralised development subsidy. I shall return to this issue and 
shall shortly consider the case of a true precautionary centralised project, with both $\partial H / \partial g$ and $d H / d g<0$, but for the time being assume that $d H / d g \geqslant 0$.

In comparing the optimal levels of ex ante development subsidy from the point of view of the Beneficiary and the Contractor, respectively, $g_{b}$ and $g_{c}$ obviously for both jurisdictions, both the marginal benefit side - the left hand side in (6) and (7) - and the marginal costs - the right hand side in (6) and (7) - matter. As for the marginal benefits, it may be plausible to think that the Beneficiary has a higher marginal benefit from any given level of $g$ than does the Contractor, but of course this need not be so. As for the marginal costs, a more determinate comparison is possible. From (6) and (7), we have that the Beneficiary has a higher marginal cost from increasing levels of the ex ante development investment $g$ if and only if:

$$
t_{b}-t_{c}>\frac{\partial H}{\partial g} s p\left(t_{b}+t_{c}\right)-p(1-s) \frac{\partial H}{\partial g}+t_{c} s p \frac{\partial H}{\partial x} \frac{\partial x_{b}}{\partial g} .
$$

Suppose that $t_{b}<t_{c}$, meaning that the Beneficiary is a relatively poor jurisdiction that pays a smaller share of the centralised development project cost than does the Contractor. If this is so, then the left-hand side in (8) is negative. Assume as a benchmark that $\partial x_{b} / \partial g=0$, that is, that in and of itself, the level of centralised spending does not affect the productivity of local precautions and therefore the optimal level of local precautions. In this case, the right-hand side of (8) can be negative and (8) can possibly hold if:

$$
s<,>\frac{1}{1+t_{c}-t_{b}} \text { as } \frac{\partial H}{\partial g}>,<0 .
$$

Inequality (9) presents two cases. It says first that when the ex ante centralised spending is truly simply a development subsidy, leading to larger development with more value at risk from the natural hazard - the case of $\partial \mathrm{H} / \partial \mathrm{g}>0$ - then the Beneficiary jurisdiction will perceive a higher marginal cost of such ex ante centralised spending whenever it bears a sufficiently high share of the ex post loss that is enhanced by such spending. If the Beneficiary is wealthy relative to the Contractor and has an even higher tax share, then it will, intuitively enough, always have a higher marginal cost of centralised development spending even if most of the ex post loss is shared with other jurisdictions. More generally, as the Beneficiary's tax share falls, it still will have higher marginal cost from spending $g$ than does the Contractor even if the Contractor bears a large share of the expenditure burden, provided that the Beneficiary bears a sufficiently large share of the ex post loss.

In the other case presented, with $\partial H / \partial g<0$, centralised ex ante spending is truly precautionary in that it reduces the value at risk from the natural hazard in the Beneficiary Jurisdiction. In this case, such spending generates both an increase in value and a decrease in potential loss in the Beneficiary jurisdiction, and an increase in value in the Contractor jurisdiction. Such spending is therefore a pure benefit to both the Beneficiary and the Contractor and the $\partial H / \partial g$ terms in (6) and (7) should be placed 
on the left hand side in those expressions rather than the right. In this case, the tax shares of $g$ alone determine the marginal cost of $g$, while the hazard reduction marginal benefit will be greater to the Beneficiary than to the Contractor provided that the Beneficiary shares a sufficiently large fraction of the ex post loss.

Of course, the marginal cost, or benefit, of increasing the ex ante centralised investment $g$ is only one thing that the Beneficiary and Contractor bargain over in the first stage of the game; they also choose the ex post centralised loss share $s$. It is to their respective optimal choices of $\mathrm{s}$ that I turn next.

\section{Optimal ex post loss sharing from the standpoint of beneficiary and contractor}

Differentiating expressions (4) and (5) with respect to the ex post centralised loss share $s$, we have for the Beneficiary and Contractor (after applying the envelope theorem to the Beneficiary expression), respectively:

$$
p H\left(g, x_{b}\right)\left(1-t_{b}\right)
$$

and,

$$
-t_{c}\left[p H\left(g, x_{b}\right)+s p \frac{\partial H}{\partial x} \frac{\partial x_{b}}{\partial s}\right] .
$$

The sign of both expressions (10) and (11) is unambiguous. From our earlier assumptions, (11) is clearly negative, meaning that a higher centralised share $s$ of the Beneficiary's ex post loss decreases the Contractor's payout: it is simply a marginal cost to the Contractor. Similarly, given that the Beneficiary optimally adjusts local precautions to the share $(1-s)$ of ex post loss that actually goes uncompensated, from (10) it is clear that an increase in the centralised share $s$ always increases the Beneficiary's net payout.

If we compare (10) and (11), we see that the Beneficiary's marginal benefit from increasing the centralised share of its ex post losses is greater than the Contractor's marginal cost of such an increase if and only if:

$$
s<\left(\frac{H}{\frac{\partial H}{\partial x} \frac{\partial x_{b}}{\partial s}}\right)\left(\frac{\left(1-t_{b}-t_{c}\right.}{t_{c}}\right) .
$$

Inequality (12) clearly depicts the possibility using centralised ex post disaster compensation to effectuate a potentially highly inefficient redistribution to Beneficiary and Contractor jurisdictions from the Loser: if both the Beneficiary and Contractor bear a small share of the cost of centralised spending (viz. both $t_{b}$ and $t_{c}$ are small), then (12) will hold even as the centralised share $s$ of ex post disaster losses goes to 1: the gain to the Beneficiary from increasing $s$ is larger than the cost to the Contractor, so that merely by increasing the ex ante development spending $g$ as well, both can be made better off. Conversely, if the tax share $t_{c}$ of the Contractor is high, then a potential joint gain to Contractor and Beneficiary from increasing the federal share $s$ 
of ex post losses will exist only if $s$ is below a threshold that is lower, the higher is the Contractor's tax share. In addition, inequality (12) does show that the incentive cost of centralised sharing of ex post losses matters: the bigger the increase in harm caused by weakened incentives - the term $(\partial H / \partial x)\left(\partial x_{b} / \partial s\right)$ - the lower is the upper found on the centralised share that is consistent with possible deals among the Beneficiary and Contractor jurisdiction.

This analysis suggests that certain coalitions of jurisdictions are likely to support high levels of centralised ex post loss sharing: coalitions of Beneficiary and Contractor jurisdictions involving Contractor jurisdictions that do not bear a large share of the cost of federal programmes.

\section{Implications for ex ante bargaining over both centralised ex post loss sharing and centralised ex ante development investments}

The analysis of the preceding two sections has the following positive implications for interjurisdictional bargaining over both the centralised share of ex post losses $s$ and the size of the centralised development investment $g$.

1. For any given set of benefits from ex ante centralised development spending, evidence that a large share of the ex post loss in Beneficiary jurisdictions is shared by other jurisdictions in the form of generous disaster relief suggests that centrally subsidised ex ante development projects did more to increase new development than to protect existing development, while conversely, evidence that a small share of losses is shared across jurisdictions suggests that the subsidised projects actually were effective in reducing risk to existing development.

2. Evidence that Beneficiary jurisdictions vote for such centralised spending even with relatively little interjurisdictional sharing of ex post losses suggests that the ex ante spending may be truly precautionary in that they reduce the value at risk in the Beneficiary jurisdiction from a natural hazard.

3. Beneficiary-Contractor jurisdictions that support very generous centralised ex post loss sharing are likely to involve Contractor jurisdictions that bear relatively low tax shares of centralised spending.

\section{Extensions}

Risk aversion and the demand for subsidised flood insurance

As explained in part I, the NFIP in the United States provides subsidised flood insurance to individuals who reside in qualified communities. As also discussed earlier, there are a number of stylised facts about the NFIP. These include the relatively low amount of coverage provided and also the relatively low participation rate. There is evidence that the provision of ad hoc ex post disaster compensation has created a moral hazard problem, cutting the demand for coverage under the NFIP. ${ }^{74}$ Here I

\footnotetext{
${ }^{74}$ Evidence on this so-called charity hazard problem is provided by Browne \& Hoyt (2000) and Rashky and Weck-Hanneman (2007).
} 
extend the earlier analysis to consider the decision of a risk-averse individual who has the opportunity to purchase subsidised flood insurance under a programme such as the NFIP but also expected the federal government to provide ex post disaster compensation. The setup tracks that set forth in Kaplow's seminal contribution. ${ }^{75}$

I consider the decision of a representative risk-averse individual living in the Beneficiary jurisdiction who has the opportunity to purchase insurance in the amount $L$ paying a price $\alpha p$, whereas before $p$ is the probability of the harm occurring. I assume that $\alpha \leqslant 1$, so that the insurance premium is less than or equal to the actuarially fair price. Let the individual's utility of wealth be given by the function $u(w)$ with $u^{\prime}>0$ but $u^{\prime \prime}<0$ to reflect risk aversion. I retain the earlier notation, but examine not the risk-neutral Beneficiary jurisdiction's decision but instead the decision of a risk-averse individual in the Beneficiary jurisdiction. That individual has to choose both a level of precautions to reduce the amount of harm she may suffer and also has to decide how much subsidised disaster (e.g. flood) insurance to buy. More formally, the individual's problem is given by:

$$
\begin{aligned}
& \max _{L, x} p\left[u\left(-c(x)-H(g, x)\left(1-s\left(1-t_{b}\right)\right)+L-\alpha p\right)\right] \\
& \quad+(1-p)[u(-c(x)-\alpha p)]-t_{b} g .
\end{aligned}
$$

Define $u_{1}=u\left(-c(x)-H(g, x)\left(1-s\left(1-t_{b}\right)+L-\alpha p\right)\right)$ and $u_{0}=u(-c(x)-\alpha p)$. The first order condition defining the individual's optimal level of subsidised insurance $L$ is then given by:

$$
p u_{1}^{\prime}(1-\alpha p)+(1-p) u_{0}^{\prime}(-\alpha p)=0
$$

or, rewriting this, by:

$$
u_{1}^{\prime}=\left(\frac{\alpha-\alpha p}{1-\alpha p}\right) u_{0}^{\prime}
$$

Risk aversion $\left(u^{\prime \prime}<0\right)$ and the assumption of subsidised insurance together imply that at the optimum described by (14), that the individual chooses a level of insurance $L$ so that she is wealthier in the no harm state 0 than in the harm state 1 . It seems natural to think that an individual will perceive that her own individual tax share of federal ex post compensation is 0 . With this simplifying assumption, risk aversion and equality (14) imply that the individual's optimal level of insurance $L^{*}$ will satisfy:

$$
L^{*} \geqslant H(g, x)(1-s)
$$

\footnotetext{
${ }^{75}$ Kaplow (1991).
} 
From (14), one can see that the individual will fully insure under an actuarially fair premium with $\alpha=1$, and that as the subsidy increases $-\alpha$ falls to $0-$ she over-insures to a greater and greater extent. But such over-insurance, it must be stressed, is only relative to the actual uncompensated loss $H(1-s)$ that she expects. If the individual expects federal taxpayers to pick up a very large share $s$ of any disaster loss that she may suffer, then she may be greatly over-insuring relative to her expected uncompensated loss even though the amount of insurance she is observed to purchase appears to be very little relative to her potential total loss $H$. Also, as the share $s$ of her loss that the individual expects federal taxpayers to compensate for free increases to 1 , her optimal amount of insurance falls to 0 .

This analysis may help explain two of the most widely commented-upon facts about the NFIP: the wide variation across states in the percentage of people who buy flood insurance, and the relatively low level of coverage that people choose. As for the low level of coverage - generally far below the NFIP limits of $\$ 250,000$ for a residential structure and $\$ 100,000$ for residential contents ${ }^{76}$ - people who live in hazard-prone but politically important states - either in terms of presidential elections or Congressional influence - may rationally expect that federal taxpayers will pick up a very large share of any disaster loss that they may suffer. The above analysis suggests that such persons would not rationally buy very large amounts of even subsidised disaster insurance. ${ }^{77}$ It also suggests that if the subsidy is large, then even the relatively small amounts that they are observed to buy may in fact amount to over-insurance. The expectation of federal disaster relief may also help explain the variation in NFIP insurance take-up across states. Florida, a state that is virtually always a key battleground state in presidential elections and which has gotten a disproportionate share of federal disaster relief, has a higher NFIP take-up rate than Texas (a reliably Republican state) ${ }^{78}$ however, a recent study ${ }^{79}$ shows that when one controls for all the variables that may explain take-up rate - such as perceived risk, wealth and whether or not the home is mortgaged - it turns out that Floridians actually are much less likely to buy flood insurance than people in other states. This would be a rational response to Floridians' expectation of generous federal ex post disaster compensation.

\section{Politically determined ex post loss sharing}

As described in Part I, it is not Congress, but the President and FEMA who determine the share $s$ of disaster loss, which is federally compensated. Moreover, this determination is made only after a disaster occurs. The empirical work surveyed earlier shows that residents of states that are battleground states in upcoming presidential elections and/or which have federal representatives on key FEMA oversight committees can expect to have the federal government pick up a large share $s$ of their disaster losses. Even when ex post disaster relief is variable, my model still generates

\footnotetext{
76 As found by Michel-Kerjan and Kousky (2010, pp. 380-382).

${ }^{77}$ For a similar argument, see Epstein (1996).

${ }^{78}$ Michel-Kerjan and Kousky (2010, p. 375).

${ }^{79}$ Petrolia et al. (2011).
} 
predictions. Perhaps the clearest prediction of my model pertains to states that do not have political influence (either on key committees or as a battleground state in presidential elections) and which are therefore known to receive far less in federal disaster relief than is warranted by the magnitude of the disasters they suffer. In as much as such states bear virtually all of any risk enhancement due to ex ante development subsidies, their representatives should demand relatively lower amounts of risk-increasing ex ante development aid. Overall, one should observe a positive correlation between federal ex ante development spending and ex post federal disaster relief, with states that lack political influence ex post getting less ex ante as well.

\section{Policies to improve beneficiary jurisdiction incentives for ex ante precaution}

As the discussion in Part I showed, perhaps the most widely understood feature of the American system of centralised (federalised) disaster relief is that it has created a severe moral hazard problem when it comes to precautions by what I have called Beneficiary jurisdictions. The bigger the share of ex post lost compensated by other jurisdictions - typically via a mix of subsidised insurance and generous ex post reliefthe weaker are local Beneficiary jurisdiction incentives to take costly steps to lower the amount at risk of loss should a natural disaster strike. On policy that has been proposed as a step to deal with the moral hazard problem is (in terms of the present model) for the Beneficiary to get the ex ante development subsidy if and only if it take a level of precautions equal to or exceeding the optimal level of precautions given the level of the subsidy. It can be shown ${ }^{80}$ that whether or not this policy induces the Beneficiary to take optimal precautions is complex, depending upon the sign of the two partial derivatives $\partial H / \partial g$ and $\partial \mathrm{x}_{\mathrm{b}} / \partial \mathrm{g}$ discussed earlier. There are three cases:

1. When $\partial H / \partial g>0$ and $\partial x_{b} / \partial g>0$ but $d H / d g>0$, the project generates increased ex post harm and precaution costs for the Beneficiary, and thus the Beneficiary will not get a positive expected payout from and vote for a project that it is conditioned on its taking optimal precautions unless either the ex post losses are very unlikely, or it is able to shift a large part of the project cost and its ex post losses to other jurisdictions.

2. When $\partial H / \partial g<0$ and $\partial x_{b} / \partial g>0$, the centralised project is both directly precautionary and also indirectly precautionary by improving the productivity of local precautions. In this case, the centralised project spending generates not only direct benefits to both the Beneficiary and the Contractor, but also big precautionary benefits to the Beneficiary, and those precautionary benefits are more significant to the Beneficiary's payout, the bigger its share of its post loss, the bigger its share of the cost of the project, and the more likely is the ex post harm.

3. When $\partial H / \partial g<0$ and $\partial x_{b} / \partial g<0$, the project has a direct precautionary impact and also substitutes for local precautions. In this case, the Beneficiary is certain to be better off with the project and the required optimal precautions than with no project, provided that the direct precautionary effect outweighs the impact or reduced local precautions, so that $d H / d g<0$.

\footnotetext{
${ }^{80}$ For more detail on the proofs of these propositions, see the working paper version of this article, Jason Scott Johnston, Disasters and Decentralization, University of Virginia Law School, December 2011.
} 
The model thus suggests that in cases where the centralised development subsidy is truly precautionary-for example, Army Corps of Engineers projects really are primarily about decreasing the risk of loss to existing development rather than incentivising additional, new development-Beneficiary jurisdictions should agree to make their receipt of centralised ex ante development spending conditional on their taking optimal precautions against ex post loss. Conversely, where the ex ante centralised development spending has the impact of increasing the net amount at risk ex post in the Beneficiary jurisdiction, then such a jurisdiction will not agree to take optimal precautions unless it pays a very small part of the cost of the ex ante development project, and/or gets a large share of its post losses compensated, and perceives a low probability of ex post loss.

\section{Conclusion}

The analysis presented here has revealed that ex ante federal development spending plays a crucial role in explaining the performance of the U.S. system of disaster relief. It has long been understood that a system that has federal taxpayers share disaster losses in risky jurisdictions may both induce overdevelopment in such jurisdictions and also reduce the local incentive to take precautions to lower ex post losses (so-called self-insurance). What has been somewhat neglected is the role of federalised ex ante development subsidies in contributing to these problems. Projects undertaken by the Army Corps of Engineers during the latter half of the $20^{\text {th }}$ century completely transformed coastal America. Those projects were typically justified as reducing natural hazard risk to existing settled areas. However, more often than not, their actual effect was not to protect existing development, but to subsidise new coastal development. Even worse, such projects often lowered the marginal productivity of local precautions to reduce loss from such hazards. The potential for climate change to increase the number or severity of natural hazards has already been set forward as a new justification for increased federal spending to protect coastal and other areas from natural hazard. If such federal spending continues to be directed towards "protective" structures that are actually designed not to protect existing development but to subsidise new development, then ex post losses from natural hazards may actually increase as a consequence of concerns over climate change.

Thus, at least in the U.S., effective precautions against harm from climate change may hinge upon curbing the level and controlling the type of ex ante federalised development subsidies that have so long masqueraded as disaster protection. Such subsidies need to be greatly reduced and limited to investments that are truly precautionary in that they protect existing investments. Centralised "precautionary" subsidies that actually are designed to increase the level of new development and which therefore increase the amount at risk should be eliminated.

Prominent existing proposals for policy reform ${ }^{81}$ call for mandating disaster insurance. The idea behind such proposals is that the local moral hazard problem caused by the provision of centrally subsidised ex post disaster compensation can be

${ }^{81}$ Dating from Kunreuther (1968); for a recent formulation, see Schwarze \& Wagner (2004). 
overcome if people in disaster-prone localities are required to buy insurance. Since the premium for such insurance should - at least in theory - be lower, the higher is the level of precautions taken locally, mandatory insurance could create an incentive for local precautions to reduce the amount at risk in natural disasters. Such proposals assume that it is politically possible to eliminate subsidies for (mandatory) disaster insurance. But the analysis in this paper shows that it is unlikely that the ex post insurance system can be reformed without also reforming the system of centralised ex ante development subsidies. In as much as such subsidies are determined in large part by the benefits they generate outside hazard-prone jurisdictions, and take a form that actually increases new development and the amount at risk in hazard-prone jurisdictions, ex ante subsidies are part of a political deal that requires subsidised disaster insurance. On my analysis, reform of the ex post compensation-insurance system cannot be effectuated without also curbing and controlling centralised subsidies for ex ante development.

\section{Acknowledgements}

I am grateful for helpful comments on earlier versions of this paper to participants in the American Law and Economics Association Annual Meeting, the second Toulouse-Montreal Conference on the Law, Economics and Management of Large-scale Risks, the law and economics workshop at Virginia, and the February, 2011 Joint Seminar on the Law and Economics of Natural Hazard Management jointly sponsored by the European Association of Law and Economics and The Geneva Association.

\section{References}

American Society of Civil Engineers (2007) The New Orleans Hurricane Protection System: What Went Wrong and Why, Reston, VA: American Society of Civil Engineers, Available at www.asce.org/ uploadedFiles/Publications/ASCE_News/.../ERPreport.pdf, accessed 30 August 2011.

Bayot, J. (2005) 'Hurricane Katrina: Insurance; Payouts Hinge on the Cause of Damage', New York Times, late edition, 31 August.

Bin, O., Bishop, J.A. and Kousky, C. (2011) 'Redistributional effects of the National Flood Insurance Program', Resources for the Future, Discussion Paper RFF-DP-114.

Browne, M.J. and Hoyt, R.E. (2000) 'The demand for flood insurance: Empirical evidence', Journal of Risk and Uncertainty 20(3): 291-306.

Burby, R.J. (2001) 'Flood insurance and floodplain management: The U.S. experience', Environmental Hazards 3(3): 111-122.

Burby, R.J. (2006) 'Hurricane Katrina and the Paradoxes of government disaster policy: Bringing about wise governmental decisions for hazardous areas', The Annals of the American Academy of Political and Social Science 604(1): 171-191.

Colten, C.E. and Sumpter, A.R. (2009) 'Social memory and resilience in New Orleans', Natural Hazards 48(3): 355-364.

Congleton, R.D. (2006) 'The story of Katrina: New Orleans and the political economy of catastrophe', Public Choice 127(2): 5-30.

Cutter, S.L. and Gall, M. (2007) 'Hurricane Katrina: A failure of planning or a planned failure?', in C. Felgentreff and T. Glade (eds.) Naturrisken und Sozialkatastrophen. Berlin, Heidelberg: Springer.

Dionne, G. and Eeckhoudt, L. (1985) 'Self-insurance, self-protection and increased risk aversion', Economics Letters 17(1-2): 39-42.

Dixon, L., Claney, N., Seabury, A. and Overton, A. (2006) The National Flood Insurance Program: Market Penetration Rate. Report for Federal Emergency Management Agency, Contract No. 282-98-0029, Rand Corporation, Santa Monica, CA. 
Downton, M.W. and Pielke Jr., R.A. (2001) 'Discretion without accountability: politics, flood damage and climate', Natural Hazards Review 2(4): 157-166.

Ehrlich, I. and Becker, G.S. (1972) 'Market insurance, self-insurance and self-protection', Journal of Political Economy 80(4): 623-648.

Epstein, R. (1996) 'Catastrophic response to catastrophic risks', Journal of Risk and Uncertainty 12(2-3): 287-308.

Garrett, T.A. and Sobel, R.S. (2003) 'The political economy of FEMA disaster payments', Economic Inquiry 41(3): 496-509.

Godschalk, D.B., Beatley, T., Berke, P., Brower, D. and Kaiser, E.T. (1999) Natural Hazard Mitigation: Recasting Disaster Policy and Planning, Washington, D.C.: Island Press.

Hird, J.A. (1994) Superfund: The Political Economy of Environmental Risk, Baltimore, MD: Johns Hopkins University Press.

Jullien, B., Salanié, B. and Salanié, F. (1999) 'Should risk averse agents exert more effort?' The Geneva Papers on Risk and Insurance Theory 24(1): 19-28.

Kane, E.J. (1996) 'Difficulties in making implicit government risk-bearing partnerships explicit', Journal of Risk \& Uncertainty 12(2-3): 189-199.

Kaplow, L. (1991) 'Incentives and government relief for risk', Journal of Risk and Uncertainty 4(2): 167-175.

Kunreuther, H. (1968) 'The case for comprehensive disaster insurance', Journal of Law \& Economics 11(1): 139-144.

Kunreuther, H. (1996) 'Mitigating disaster losses through insurance', Journal of Risk \& Uncertainty 12(1): 171-187.

Kunreuther, H. and Pauly, M. (2006) 'Rules rather than discretion: Lesson from Hurricane Katrina', Journal of Risk \& Uncertainty 33(1-2): 101-116.

Lehrer, E. (2008) Reforming the National Flood Insurance Program after 35 years of failure, Competitive Enterprise Institute, No. 2.

Lewis, C.M. and Murdock, K.C. (1999) 'Alternative means of distributing catastrophic risk in a national risk-management system', in K.A. Froot (ed.) The Financing of Catastrophic Risk, Cambridge, MA: National Bureau of Economic Research.

Marron, D.B. (2006) The Budgetary Treatment of Subsidies in the National Flood Insurance Program, Statement before the Committee on Banking, Housing, and Urban Affairs, U.S. Senate. Washington, D.C.: Congressional Budget Office.

May, P. (1985) Recovering from Catastrophe: Federal Disaster Relief Policy and Politics, New York: Greenwood Press.

Mileti, D.S. (2001) Disasters by Design: A Reassessment of Natural Hazards in the United States, Cambridge, MA: Joseph Henry Press.

Michel-Kerjan, E.O. (2010) 'Catastrophe economics: The new National Flood Insurance Program', Journal of Economic Perspectives 24(4): 165-186.

Michel-Kerjan, E.O. and Kousky, C. (2010) 'Come rain or shine: Evidence on flood insurance purchases in Florida', Journal of Risk and Insurance 77(2): 369-397.

Petrolia, D.R., Landry, C.E. and Coble, K.H. (2011) 'Risk preferences, risk perceptions and demand for flood insurance, from http://papers.ssrn.com/sol3/papers.cfm?abstract_id $=1843326$.

Pielke Jr., R.A. and Landsea, C.W. (1998) 'Normalized Hurricane damages in the United States: 1925-1995', Weather \& Forecasting 13(3): 621-631.

Pielke Jr., R.A., Gratz, J., Landsea, C.W., Collins, D., Saunders, M.A. and Musulin, R. (2008) 'Normalized Hurricane damages in the United States: 1900-2005', Natural Hazards 9(1): 29-42.

Platt, R.H. (1999) Disasters and Democracy: The Politics of Extreme Natural Events, Washington, D.C.: Island Press.

Pompe, J.J. and Rinehart, J.R. (2008) 'Property insurance for coastal residents: Government's "ill wind", Independent Review 13(2): 189-207.

Rashky, P.A. and Weck-Hanneman, H. (2007) 'Charity hazard: A real hazard to natural disaster insurance?' Environmental Hazards 7(4): 321-329.

Reeves, A. (2011) 'Political disaster: Unilateral powers, electoral incentives, and presidential disaster declarations', Journal of Politics 73(4): 1142-1151. 
256

Schwarze, R. and Wagner, G. (2004) 'In the aftermath of Dresden: New directions in German flood insurance', The Geneva Papers on Risk and Insurance-Issues and Practice 29(2): 154-168.

Shallat, T. (2000) 'In the wake of hurricane Betsy', in C. Colten (ed.) Transforming New Orleans and its Environs: Centuries of Change, Pittsburgh: University of Pittsburgh Press, p. 121.

Shugart, W.F. (2006) 'Katrinanomics: The politics and economics of disaster relief', Public Choice 127(1-2): 31-53.

Shugart, W.F. (2011) 'Disaster relief as bad public policy', The Independent Review 15(4): 519-539.

Sobel, R.S. and Leeson, P.T. (2006) 'Government's response to Hurricane Katrina: A public choice analysis', Public Choice 127(1): 55-73.

Wisner, B., Blaikie, P., Cannon, T. and Davis, I. (2004) At Risk: Natural Hazards, People's Vulnerability and Disasters, 2nd edn. London and New York: Routledge.

Young, A.T. (2008) 'Replacing incomplete markets with a complete mess: Katrina and the NFIP', International Journal of Social Economics 35(8): 561-568.

\begin{abstract}
About the Author
Jason Scott Johnston is the Henry I. and Grace Doherty Charitable Foundation Professor of Law and the Nicholas E. Chimicles Research Professor in Business Law and Regulation at the University of Virginia Law School. He is the author of dozens of articles on a variety of topics concerning the law and economics of regulation in journals such as the Yale Law Journal and the Journal of Law, Economics and Organization, and is coordination of the Searle Workshops on Markets and the Environment at the University or Virginia.
\end{abstract}

